\title{
KEBERADAAN KEBUTUHAN EXISTENCE, RELATEDNESS, DAN GROWTHDALAM VIDEO GAME HARVEST MOON BACK TO NATURE
}

\author{
Arief Budiman \\ Program Studi Desain Komunikasi Visual Universitas Telkom \\ ariefiink@telkomuniversity.ac.id
}

\begin{abstract}
Playing video games is basically an activity where it must have an stimulus energy which is commonly referred to as motivation. Without motivation, player will not be interested in playing a video game with a long duration. The Harvest Moon Back to Nature video game as a video game that was quite successful, which made the video game a legendary video game for the audience's audience as early as 1997. Harvest Moon Back to Nature looks so strong in representating about social life of rural communities, especially one who works as a farmer. It creates interest which in turn encourages researchers to know more about how motivation for human needs is presented by the Harvest Moon Back to Nature video game. This research fundamentally use interpretative analytical descriptive method with narrative approach. Using a view from ERG theory Clayton Alderfer, which according to him motivation is related to basic human needs which consist of existence needs, relatedness needs, and growth needs. In increasing one's motivation, the three basic human needs must be fulfilled wherever possible. From the results of the research conducted using these instruments, it can be concluded that the power of motivation has been presented in the Harvest Moon Back to Nature video game from the fulfillment of existence needs, relatedness needs, and growth needs, both in the context events of farming, raising, and in carrying out other events.
\end{abstract}

Keywords : motivation, existence needs, relatedness needs, and growth needs.

\begin{abstract}
ABSTRAK
Bermain video game pada dasarnya adalah suatu aktivitas yang dimana aktivitas tersebut haruslah mempunyai energi pengerak yang biasa disebut sebagai motivasi. Tanpa sebuah motivasi maka pemain tidak akan tertarik dalam memainkan suatu video game dengan durasi waktu yang cukup lama. Video Game Harvest Moon Back to Nature sebagai video game yang cukup sukses, dan legendaris bagi para publik penikmatnya semanjak kemunculan perdananya di tahun 1997. Video game Harvest Moon Back to Nature tersebut terlihat begitu kental merepresentasikan tentang kehidupan sosial masyarakat perdesaan khususnya seorang yang berprofesi sebagai petani. Dari hal tersebutlah menimbulkan ketertarikan peneliti untuk mengetahui lebih dalam terhadap bagaimana motivasi kebutuhan manusia dihadirkan video game Harvest Moon Back to Nature. Penelitian ini pada prinsipnya mempergunakan metode deskriptif analitik interpretative dengan pendekatan naratif. Dengan mengunakan sebuah pandangan dari teori ERG Clayton Alderfer, yang menurutnya motivasi itu berkaitan dengan kebutuhan pokok manusia yang terdiri dari kebutuhan eksistensi (existence needs), kebutuhan berhubungan (relatedness needs), dan kebutuhan pertumbuhan (growth needs). Dalam meningkatkan motivasi seseorang maka ketiga kebutuhan pokok manusia tersebut sedapat mungkin haruslah terpenuhi. Dari hasil penelitian yang dilakukan dengan mengunakan instrument tersebut, dapat disimpulkan bahwa kekuatan motivasi telah dihadirkan didalam video game Harvest Moon Back to Nature dari keberadaan pemenuhan kebutuhan eksistensi, kebutuhan berhubungan, dan kebutuhan pertumbuhan, baik dalam konteks peristiwa bertani, beternak, serta dalam menjalankan peristiwa lainnya.
\end{abstract}

Kata kunci: motivasi, kebutuhan eksistensi, kebutuhan berhubungan, dan kebutuhan pertumbuhan. 


\section{PENDAHULUAN}

Keberadaan video game saat ini telah bertransformasi menjadi sebuah media popular yang membius berbagai lapisan genereasi serta kalangan masyarakat. Bukan hanya karena kemajuan teknologinya saja yang menjadikan keberadaan video game menjadi media yang cukup digemari, namun peranan dari konten gameplay pun cukup menjadi salah satu aspek yang patut di apresiasi. Konten gameplay dalam sebuah video game saat ini sangat berpengaruh luar biasa dalam menarik, mempertahankan, hingga memproduksi wacana di dalam kalangan gamers. Keberadaan pemain di dalam dunia video game tentu mempunyai berbagai macam motif untuk dapat bertahan dalam bermain video game dengan waktu yang cukup lama. Sehingga konten video game sejatinya haruslah dapat menyediakan ruang aktivitas yang dimana aktivitas tersebut memiliki motif yang dapat menghadirkan motivasi bagi pemain untuk dapat bertahan.

Keberadaan motif memberikan dampak motivasi yang sangat besar untuk dapat menarik, mempertahankan hingga mendorong pemain dalam melaksanakan sesuatu yang telah ditetapkan. Karena motivasi pada dasarnya merupakan suatu kondisi mental seseorang yang mendorong untuk melakukan suatu tindakan (action) dan mem- berikan kekuatan yang mengarah kepada pencapaian kebutuhan (Robbins, 2001). Motivasi menimbulkan dorongan untuk pencapaian pemenuhan kebutuhan, seperti yang dituturkan Alderfer (dalam Siagian, 2005) motivasi kerja dan pemenuhan kebutuhan memiliki keterkaitan yang cukup erat.

Dengan meminjam pemaparan diatas dapat dipersepsikan bahwa motivasi hadir di dalam konten video game dikarenakan adanya sebuah rancangan yang matang ter-hadap aspek pemenuhan kebutuhan. Dari pemaparan tersebut peneliti merasa tertarik untuk melihat bagaimana aspek kebutuhan sebagai motif dapat meng-hadirkan sebuah motivasi dalam bermain video game. Hal tersebut dapat menjadi pembahasan yang cukup menarik untuk dikaji lebih mendalam. Peneliti akan menganalisis kehadiran motivasi tersebut dengan teori kebutuhan manusia dari Clayton Alderfer yang sudah banyak dikenal sebagai teori ERG yang didasarkan pada kebutuhan manusia akan keberadaan (exsistence), hubungan (relatedness) dan pertumbuhan (growth).

\section{Objek Kajian}

Dari sekian banyaknya video game, peneliti tertarik terhadap video game Harvest Moon Back to Nature yang nantinya akan dijadikan sebagai objek kajian. Ketertarikan peneliti terhadap 
video game tersebut didasari dengan berbagai alasan tentunya. Salah satu di antaranya dikarenakan video game Harvest Moon Back to Nature telah mampu bertahan di benak publik penikmatnya dari berbagai lapisan yang berbeda ham-pir dua dekade lamanya.

Video game Harvest Moon Back to Nature memulai masa jayanya di Indonesia ketika dirilis untuk pertama kalinya oleh Sony Playstation pada tahun 1997. Dapat dikatakan video game Harvest Moon Back to Nature sebagai video game yang cukup sukses, yang menjadikan video game tersebut menjadi video game legendaris bagi para publik penikmatnya. Video game Harvest Moon Back to Nature tersebut terlihat begitu kental merepresentasikan tentang ke-hidupan sosial masyarakat perdesaan khususnya seorang yang berprofesi se-bagai petani.

Pemain diajak masuk dalam ruang simulasi untuk menjadi seorang petani yang dalam kehidupannya harus ber-ladang, berternak, bersosialisasi hingga mengikuti pertandingan yang diseleng-garakan oleh penduduk sekitar. Video game Harvest Moon Back to Nature dibuat sedemikian rupa, sehingga mampu menghasilkan gameplay yang sangat menarik seperti sihir yang sangat dina-mis, tidak membosankan, dan dapat membawa pemain masuk ke dalam arus kesadaran narasi (stream of consciousness) dalam memainkan video game ini.

\section{Metode Penelitian}

Penelitian ini memanfaatkan cara penafsiran dengan menyajikannya dalam bentuk deskripsi dengan mengunakan metode kualitatif. Dalam penelitian ini pada prinsipnya mempergunakan metode deskriptif analitik interpretatif dengan pendekatan naratif. Metode deskriptif analitik interpretatif digunakan sebagai metode untuk menguraikan objek, menganalisis, serta mengiterpretasikannya.

Data dan fakta yang diperoleh kemudian diurai, diklasifikasikan, dan dianalisis untuk memperoleh gambaran secara terperinci sehingga menghasilkan kesimpulan yang bisa dipertanggungjawabkan. Sedangkan metode interpretatif sebagai langkah penutup dalam analisis data dengan cara mengambil kesimpulan secara keseluruhan.

Teori yang digunakan penelitian ini adalah Teori kebutuhan manusia Alderfer yang biasa dikenal dengan teori "ERG", teori yang mengadopsi dari teori motivasi kebutuhan manusia yang pernah diungkap oleh Abraham Maslow. Seperti yang diungkapkan Alderfer dalam Robbins (2001:171), mengatakan ada tiga kebutuhan dasar manusia seperti; kebutuhan eksistensi (existence), kebutuhan berhubungan (relatedness), dan kebutuhan pertumbuhan (growth). Berikut adalah uraian dari teori ERG Alderfer; 


\section{Kebutuhan Eksistensi}

Kebutuhan eksistensi merupakan pem-berian persyaratan eksistensi materil dasar, mencakup butir-butir yang oleh Maslow dianggap sebagai kebutuhan keamanan serta keselamatan dan kebutuhan fisiologis seperti gaji, kondisi kerja, peralatan kerja atau kebutuhan mendasar manusia untuk bertahan hidup dan sebagainya.

\section{a. Kebutuhan Berhubungan,}

Kebutuhan berhubungan merupakan hasrat yang kita miliki untuk memelihara hubungan antar pribadi yang bermanfaat. Hasrat sosial dan status menuntut interaksi dengan orang-orang lain agar dipuaskan, dan hasrat ini segaris dengan kebutuhan sosial Maslow.

\section{b. Kebutuhan Pertumbuhan,}

Kebutuhan pertumbuhan adalah suatu hasrat instrinsik untuk perkembangan pribadi, mencakup komponen instriksi dari kategori penghargaan Maslow dan karakteristik - karakteristik yang tercakup pada aktualisasi diri.

\section{PEMBAHASAN}

Pengunaan sebuah teori ERG Alderfer yang berbicara tentang motivasi kebutuhan manusia pada umumnya digunakan dalam motivasi organisasi dan motivasi berkerja. Saat ini peneliti mencoba mengunakan teori tersebut untuk melihat motivasi kebutuhan manusia yang dihadirkan dalam konten video game Harvest Moon Back to Nature. Hal tersebut dilandasi dengan adanya beberapa kolerasi yang dapat dikaitkan seperti, kedua - duanya mempunyai tujuan yang sama untuk mencoba mempertahankan seseorang (pegawai/ pemain) untuk dapat terus beraktivitas dengan tujuan yang telah ditetapkan. Dalam sebuah tempat bekerja pegawai akan termotivasi bekerja dan bertahan cukup lama ababila perusahaan tersebut memberikan sebuah peluang kebutuhan untuk berkembang, peluang kebutuhan untuk membuktikan diri, serta peluang kebutuhan untuk memiliki banyak pertemanan atau relasi. Terkait dengan hal tersebut maka menarik mengunakan teori ERG dalam membedah sebuah peluang - peluang kebutuhan manusia yang dihadirkan dalam video game Harvest Moon Back to Nature sebagai bentuk terbentuknya motivasi agar pemain dapat terus berada dalam ruang bermain.

Dari hasil observasi terhadap video game Harvest Moon Back to Nature, video game tersebut memiliki tujuan untuk melanjutkan kehidupan bertani di lahan yang telah diwariskan oleh sang kakek. Video game Harvest Moon Back to Nature dituturkan dengan pola non- 
linear. Pemain dapat memulai dengan awal pilihan yang berbeda - beda, tetapi tetap memiliki beberapa ketentuan yang bersifat parsial. Dalam memainkan video game Harvest Moon Back to Nature pemain akan menjumpai peristiwa peristiwa yang akan dialami oleh pemain dalam setiap memainkan video game Harvest Moon Back to Nature diantaranya adalah; (1) peristiwa bertani; menanam dan memanen, (2) peristiwa berternak; ayam, sapi, domba, (3) peristiwa bersosialisasi; mencari pasangan hidup, mencari resep makanan, mencari sang pencuri, menyenangkan hari masyarakat, (4) peristiwa berfestival; tomat, kembang api, musik, hasil panen, melihat bulan, masak, tahun baru , (5) peristiwa bertanding; pertandingan ayam, pertandingan sapi, pertandingan domba, pertandingan anjing peliharaan, pertandingan kuda, dan pertandingan berenang. Melalui peristiwa - peristiwa tersebut peneliti akan membahas bagaimana penerapan kebutuhan eksistensi, kebutuhan berhubungan, kebutuhan pertumbuhan dalam video game Harvest Moon Back to Nature (sumber: data pribadi).

\section{Kebutuhan Berhubungan (Relatedness needs)}

Kebutuhan berhubungan dapat dikatakan keinginan yang seseorang miliki agar mendapatkan hubungan antar se- sama manusia yang bermanfaat. Dalam video game Harvest Moon Back to Nature terdapat peristiwa bersosialisasi yang pemain diberikan kesempatan untuk menjalin hubungan dengan masyarakat desa Mineral Twon agar dapat mendapatkan kebermanfaatan dari hasil hubungan baik yang terjalin. Tentunya tidak semua peristiwa dalam video game Harvest Moon Back to Na-ture terkait langsung dengan kebutuhan berhubungan (Relatedness needs), hanya beberapa peristiwa game saja yang diantaranya seperti, peristiwa bersosialisasi dan peristiwa festival.

\section{- Bersosialisasi}

Dalam memainkan video game Harvest Moon Back to Nature pemain diajak untuk menjalankan kehidupan di dalam sebuah desa yang diberi nama desa Mineral Town. Desa tersebut dihuni dengan berbagai kalangan sosial masyarakat yang berbeda - beda, dan terdapat 40 karakter di desa Mineral Town. Dengan banyaknya karakter yang ditampilkan dalam video game ini maka peristiwa bersosialisasi menjadi peristiwa yang tidak dapat dihindarkan dalam memainkan video game ini. Peristiwa bersosialisasi menjadi peristiwa yang cukup banyak menghabiskan waktu bermain. Pemain harus meluangkan waktu untuk dapat mengunjungi warga, berbicara dengan mereka, hingga meng- 
ikuti beberapa kegiatan rutin yang dilakukan oleh warga di desa Mineral Town. Apabila pemain dengan konsisten dapat melakukan beberapa hal tersebut maka pemain akan mendapatkan beberapa informasi bermanfaat dari hasil interaksi tersebut, hal sebaliknya apabila pemain tidak dapat menjalin hubungan baik dengan warga, pemain tidak akan mendapatkan informasi - informasi berharga. Informasi - informasi berharga tersebut tentu berhubungan dengan dengan beberapa peristiwa lainnya seperti; peristiwa bertani, peristiwa beternak, peristiwa festival, dan peristiwa pertandingan. Informasi berharga tersebut tentunya tidak didapat dengan mudah oleh pemain, pemain diharuskan melakukan beberapa kegiatan hingga mengetahui apa yang disukai oleh setiap karakter yang ada agar dapat meningkatkan rasa kepercayaan hingga perasaan senang yang dirasakan oleh warga Mineral Town.

\section{- Festival}

Festival menjadi salah satu peristiwa yang cukup unik karna menampilkan beberapa kegiatan yang berhubungan dengan hasil panen serta kebudayaan dan hanya dilakukan 1 tahun sekali setiap peristiwanya. Pemain diharapkan mengikuti di setiap kegiatan festival tersebut karna dengan mengikuti kegiatan festival tersebut maka akan mempererat hubungan dengan warga di desa Mineral Twon.

\section{Kebutuhan Pertumbuhan (Growth needs)}

Kebutuhan pertumbuhan (Growth needs) sejatinya dibutuhkan oleh seseorang untuk dapat mengembangkan potensi - potensi yang dimilikinya agar dapat berpengaruh langsung terhadap dirinya maupu terhadap lingkungannya. Dalam video game Harvest Moon Back to Nature akan dilihat bagaimana video game ini menyediakan kebutuhan perkembangan untuk mengembangkan potensi dan kreativitas pemain.

\section{-Bertani}

Dalam memainkan video game Harvest Moon Back to Nature, bertani adalah peristiwa utama yang pemain akan mainkan, begitu banyak kegiatan kegiatan yang akan dilakukan oleh pemain. Kegiatan - kegitan tersebut berupa simulasi layaknya seorang petani, dimulai dari merapihkan lahan yang sudah lama tidak terpakai, menggemburkan tanah, menyebar bibit tanam, menyiram, memanen hasil tanam, hingga menjual hasil panen. Terdapat begitu banyak pilihan varian tanaman buah, tanaman sayur dan varian bunga yang dapat ditanam di ladang. Varian - varian tanaman pun memiliki nilai jual dan durasi panen dan waktu tanam yang berbeda - 
beda. Pemain harus dapat menentukan strategi dalam menentukan tanaman yang akan dipilih terkait dengan, sumberdaya tenaga untuk mengurus tanaman, waktu musim tanam, kemampuan membeli bibit, hingga penghasilan yang akan di dapat. Bibit tanaman tersebut sebagian dijual di supermartket, hanya saja bibit - bibit yang dijual di supermarket mempunyai nilai jual yang tidak begitu tinggi. Ada beberapa bibit tanaman yang mempunyai nilai jual tinggi seperti buah nanas yang tidak dijual di supermarket, bibit tersebut hanya dapat dibeli oleh pemain di luar supermatket. Pemain akan mengetahui penjual bibit tersebut apabila pemain melakukan interaksi dengan warga dan penjual tentang keberadaan dan waktu sang penjual menjual bibit tersebut.

Pada peristiwa game bertani pemain membutuhkan alat-alat pendukung dalam menyelesaikan pekerjaannya. Alat -alat untuk mendukung dalam aktivitas tersebut seperti; pacul, cerurit, penyiram, kampak, dan palu. Pacul diperlukan untuk mengemburkan tanah sebelum memulai menyebar bibit tanaman, cerurit dibutuhkan untuk membersihkan lahan yang dari rumput - rumput liar, penyiram dibutuhkan pada saat waktu untuk mesiram tanaman, kampak digunakan untuk menebang pohon dan mengumpulkan kayu, sedangkan palu digunakan untuk menghancurkan bebatuan yang meng- halangi area lahan tanam. Kelima alat tersebut dapat mengalami peningkatan kemampuan agar dapat meringankan beban pekerjaan pemain pada saat bertani. Dalam meningkatkan kelima alat tersebut dapat dibagi menjadi empat tahap peningkatan. Beberapa hal yang harus dipenuhi dalam meningkatkan alat - alat tersebut seperti diantaranya, metingkatkan level pemakaian yangdi bagi menjadi empat tahap yaitu $100 \%$ singga $400 \%$, selain itu pemain pun harus membutuhkan hasil tambang sebagi syarat dalam mengingkatkan kemampuan alat tersebut. Selain alat - alat keperluan bertani pemain pun dapat melakukan pengembangan untuk keperluan bertani dengan membuat rumah kaca yang dapat digunakan untuk menanam jenis tanaman apapun tanpa harus menunggu musim tanam.

\section{- Berternak}

Beternak menjadi peristiwa game yang cukup dapat diandalkan dalam menghasilkan finansial selain dari peristiwa game bertani. Pemain dapat memiliki hewan ternak seperti; sapi, domba, ayam, dan ikan. Pada peristiwa tersebut pemain dapat membeli, menambah, membesarkan, meningkatkan kapasitas kandang, hingga dapat menjual hasil dari berternak hewan - hewan tersebut untuk dijual. Pemain secara tidak langsung dituntut untuk melakukan 
pengembangan dari usaha beternak untuk mendapatkan finansial yang lebih banyak.

Pada awal permainan pemain hanya disediakan kolam ikan, kandang ayam, kandang sapi dan domba, yang kosong tanpa ada hewan peliharaan. Pemain diberikan pilihan untuk memelihara dan mengisi kandang yang disediakan dengan cara membeli ayam, sapi dan domba sedangkan ikan hanya didapat dengan cara memancing. Pemain harus merawat hewan - hewan yang telah dimiliki dengan memberikan pakan ternak, membersihkan hewan ternak dan mengajak berbicara hewan tesebut agar hewan tersebut bahagia. Karena dalam peristiwa game ini peningkatan dari kebahagian setiap hewan yang dipelihara cukup dapat berpengaruh pada hasil ternak yang dihasilkan. Tanpa melakukan rutinitas tersebut setiap harinya maka hewan hewan peliharaan yang dimiliki tidak mungkin dapat menghasilkan hasil yang maksimal. Pemain dapat melihat perkembangan Indikator nilai kebahagiaan dari hewan ternak dari tampilan interface dalam game ini.

Selain harus memperhatikan perkembangan hewan ternak yang dimilikinya, pemain dapat membangun kandang - kandang hewan ternak seperti kandang ayam, kandang sapi dan domba menjadi lebih besar. Dengan melakukan peningkatan kandang hewan ternak maka pemain dapat menambah jumlah hewan ternak yang dipelihara dengan batas maksimal 10 ekor untuk hewan ternak ayam, sapi dan domba. Terbagi menjadi tiga tahapan dalam membangun kandang - kandang tersebut.

Adapun ketentuan ketentuan yang harus dipenuhi dalam membangun kandang tersebut yaitu jumlah kayu yang dikumpulkan dan jumlah mahar uang yang harus disediakan. Selain dari kandang pemain pun dapat melakukan pembelian sebuah alat untuk mengolah hasil dari hewan ternak seperti mesin pembuat keju dari susu yang dihasilkan dan mesin pembuat benang wol dari bulu domba yang dihasilkan.

\section{Kebutuhan Eksistensi (Relatedness needs)}

Kebutuhan eksistensial sangat erat hubungannya terhadap hal yang terkait dengan kebutuhan paling mendasar dalam mempertahankan hidup. Kebutuhan ini adalah kebutuhan penunjang kehidupan dan keamanan bagi seseorang seperti; finansial, makanan, kesehatan, dan tempat tinggal. Berikut adalah penjabaran mengenai konten bermain yang disediakan dalam video game Harvers Moon Back to Nature terhadap kebutuhan yang paling mendasar pemain dalam keberadaanya di desa Mineral Twon. 
Pada video game Harvest Moon Back to Nature pemain akan mendapatkan uang dari keuntungan menjual hasil panen bertani dan beternak. Besar kecilnya pendapatan keuangan ditentukan dari hasil jerih payah kerja yang dilakukan oleh pemain, pemain diberikan kebebasan untuk menentukan sendiri penghasilan yang akan diperolehnya. Semakin banyak tanaman yang ditanam serta semakin banyaknya hewan ternak yang dipelihara makan hasil pendapatannya pun akan semakin besar. Pada awal permainan pun pemain sudah diberikan rumah dan kandang ternak dengan kondisi yang masih sederhana. Pemain diberikan kesempatan untuk meningkatkan kapasitas kandang serta merenovasi rumah menjadi lebih besar.

Peningkatan kapasitas kandang selain memberikan daya tampung yang lebih besar, keberadaanya pun dapat terkait dengan keamanan hewan - hewan ternak dari serangan srigala dan badai ketika berada di laur kandang. Sedangkan renovasi rumah diperuntukanan untuk menambah fasilitas yang didapat dalam rumah seperti dapur dan kamar tidur. Dengan keberadaan dapur kita dapat berekplorasi untuk membuat makanan dari hasil panen. Dengan kita dapat memasak ada beberapa keuntungan yang akan didapat diantaranya pemain dapat mengikuti festival memasak dan dapat memberikan hadiah masakan yang disukai pada setiap warga Mineral Twon. Dengan kita telah merenovasi rumah hingga level 3 batas level tertinggi maka kita telah dapat untuk menikahi salah satu dari lima gadis yang ada di desa Mineral Twon. Terdapat pula beberapa fasilitas publik yang ada di desa Mineral Twon seperti disediakannya klinik kesehan untuk mendapatkan perawatan apabila pemain mengalami kelelahan dalam menjalankan aktivitasnya, tempat beribadah, supermarket yang menjual segala kebutuhan pemain dari bibit hingga makanan, dan adapula sebuah lapangan untuk tempat berkumpulnya warga, yang dapat dimanfaatkan oleh pemain.

\section{SIMPULAN}

Melihat dari penjabaran diskripsi terhadap peristiwa - peristiwa yang ada di dalam permainan video game Harvest Moon Back to Nature dapat disimpulkan konten video game tersebut menyediakan sebuah kebutuhan - kebutuhan manusia seperti, kebutuhan eksistensi, kebutuhan berhubungan, dan kebutuhan pertumbuhan sebagai bentuk motivasi dalam bekerja di desa Mineral Twon.

Pertama, dari keberadaan kebutuhan eksistensi konten video game Harvest Moon Back to Nature menyediakan kebutuhan - kebutuhan dasar bagi seseorang petani seperti, modal awal berupa finansial dan asset bangunan 
untuk memulai usaha, rumah sebagai tempat tinggal untuk memberikan nilai kemanan, klinik untuk menjamin kesehatan, serta beberapa sumber makananan.

Kedua, dari kebutuhan berhubungan konten video game ini memberikan sebuah ruang untuk pemain dapat menjadi sosialisasi dengan warga agar mendapatkan beberapa informasi informasi yang bermanfaat untuk keberlangsungan perkembangan dari usaha yang dijalankannya. Ketiga, kebutuhan pertumbuhan disini dapat pemain rasakan bagaimana konten video game menyediakan sebuah fitur untuk up-grade (meningkatkan) peralatan, kandang ternak, hingga tempat tinggal. Fitur tersebut dapat pemain sebagai bentuk aktualisasi diri di dalam bermain video game Harvest Moon Back to Nature.

Ketiga kebutuhan manusia (eksistensi, berhubungan, pertumbuhan) tersebut disajikan secara non-linear di dalam konten video game Harvest Moon Back to Nature. Pertimbangan tersebut lebih banyak didasarkan kepada sifat naluriah yang melekat pada diri manusia, hal tersebut wajar karena video game ini mengadopsi dari sebuah kehidupan sosial masyarakat perdesaan khususnya seorang yang berprofesi sebagai petani.

Artinya, dengan menyadari keterbatasannya pemain dapat memusatkan perhatiannya kepada peristiwa - peristiwa yang mungkin dapat dikerjakannya. Sehingga setiap peristiwa yang berkolerasi dengan peristiwa lainnya dapat mendorong pemain untuk mencapai dan memperoleh sesuatu sesuai dengan yang telah ditargetkannya. Dapat dikatakan bahwa kekuatan motivasi telah dihadirkan dalam konten video game Harvest Moon Back to Nature dari keberadaan pemenuhan kebutuhan eksistensi, kebutuhan berhubungan, dan kebutuhan pertumbuhan, baik dalam konteks peristiwa bertani, beternak, serta dalam menjalankan peristiwa lainnya.

\section{DAFTAR PUSTAKA}

Eriyanto. 2012, Analisis Wacana, Pengantar Analisis Teks Media, Yogyakarta, LKIS

Jaeni.2012. Komunikasi Estetik: Menggagas Kajian Seni dari Peristiwa Komunikasi Pertunjukan. IPB Press.

Moleong Lexy J. 2004, Metodologi Penelitian Kualitatif, Bandung: Remaja Rosdakarya.

Kutha Ratna, S.U, Estetika Sastra dan Budaya, Pustaka Pelajar

Robbins, Stepen P. 2001. Perilaku Organisasi. Edisi pertama. PT. Indeks, Kelompok Gramedia. Jakarta.

Sedarmayanti. (2009). Sumber Daya Manusia dan Produktivitas Kerja. Bandung: CV Mandar Maju. 
Mangkunergara. (2013). Manajemen

Sumber Daya Manusia Perusahaan. Bandung: Remaja Rosdakarya.

Siagian, Sondang P., (2005), Teori Motivasi dan Aplikasinya, Jakarta : Rieneka Cipta. 